Original Research

\title{
Impact of Economic Openness and Innovations on the Environment: a New Look into ASEAN Countries
}

\author{
Xuhua Hu${ }^{1}$, Najabat Ali ${ }^{1 *}$, Muhammad Malik ${ }^{2}$, Jamal Hussain ${ }^{3}$, \\ Jiang Fengyi ${ }^{4}$, Memoona Nilofar ${ }^{5}$ \\ ${ }^{1}$ School of Finance and Economics, Jiangsu University, 212013 Zhenjiang, China \\ ${ }^{2}$ Faculty of Management and Economics, Kunming University of Science and Technology, 650000 Yunnan, China \\ ${ }^{3}$ China Western Economics Research Centre, Southwestern University of Finance and Economics, \\ 611130, Chengdu, China \\ ${ }^{4}$ Shanghai Academy of Fine Arts, Shanghai University, 200444 Shanghai, China \\ ${ }^{5}$ Karakoram International University, Gilgit Baltistan, Pakistan
}

Received: 2 October 2020

Accepted: 26 November 2020

\begin{abstract}
This study aims to investigate the effects of economic openness and innovations on the environment of ASEAN countries for 1990-2014. We have employed several techniques for empirical analysis. To examine cross-sectional dependence and unit root test, we have used the Pesaran CD test and Pesaran CIPS unit root test. Pedroni and Kao and Westurland cointegration tests have been employed to confirm the cointegration among the variables. For estimations of long-run relationship, we have utilized DOLS and FMOLS techniques. Moreover, to determine the causality directions, we have employed Dumitrescu-Hurlin causality test. The results of the study show that energy use and trade openness significantly increase $\mathrm{CO}_{2}$ emissions in ASEAN countries. On the other hand, FDI, GDP and patents markedly depress $\mathrm{CO}_{2}$ emissions. The findings depict that energy use and trade openness harm the environment by escalating $\mathrm{CO}_{2}$ emissions while FDI, GDP and patents improve the environment by depressing $\mathrm{CO}_{2}$ emissions. Therefore, policy-makers should encourage investment in renewable energy sources and boost green trade openness in ASEAN countries.
\end{abstract}

Keywords: economic openness, innovations, $\mathrm{CO}_{2}$ emissions, environment, ASEAN countries

*e-mail: alinajabat@hotmail.com 


\section{Introduction}

In the last couple of years, FDI, trade openness and economic growth have received an enormous concentration of researchers and policy-makers due to their substantial environmental effects. FDI and trade openness boosts global manufacturing and energy utilization. This expansion of international manufacturing and energy use have drastically affected the environment all over the world. The statistics of the International Energy Agency (IEA) show that the global $\mathrm{CO}_{2}$ emissions and energy consumption increased annually by $2 \%$ between 1997 and 2015 [1]. The developing economies have received more severe results of environmental degradation due to their weak ecosystems [2]. The rise in economic growth results in deteriorating environmental sustainability. Therefore, sustainable economic growth policy has drawn the attention of many researchers and policy-makers. For sustainable economic development, reduction of $\mathrm{CO}_{2}$ emissions is very crucial because it is a hurdle in the way of environmental sustainability [3]. Innovation has become a key focus in the policy discussions of environmental sustainability due to its capability to deal with the effects of FDI, trade openness and economic growth on the environment [4]. Therefore, innovation appeared as an essential tool to achieve energy-efficient production, and it ensures sustainable development in both the developing and developed world. FDI, trade openness, economic growth, energy consumption and urbanization rise $\mathrm{CO}_{2}$ emissions because these variables mainly rely on fossil fuel energy sources $[5,6]$. Transforming to sustainable energy sources from fossil fuel energy production requires modern technologies and sustainable energy policies [7,8]. It will promote economic growth and development without deteriorating the environment.

Many studies have analyzed the association between FDI, trade openness, economic growth and environment for instance [2, 4, 9-14]. A famous Environmental Kuznets Curve (EKC) hypothesis specifies that the association between economic growth and environment have a U-shaped curve. EKC is defined as an increase in economic growth and development results in the rise of environmental pollution [15]. According to EKC theory, income and emissions are directly proportional to each other as the higher level of economic activity would lead to a higher level of energy consumption and could result in a higher level of emissions [16]. However, innovation can mitigate the effects of $\mathrm{CO}_{2}$ emissions [17]. Technological innovation can play an essential role in reducing emissions. The existing studies reveal that FDI, trade openness and economic growth have a tendency to increase pollution, but technological innovation reduces the adverse environmental effects by mitigating $\mathrm{CO}_{2}$ emissions. In the endogenous growth theory, technological innovation has a positive impact on the environment, as it enhances environmental friendly production sources by substituting pollutant sources. It implies that technological innovation can reduce pollution without affecting economic growth [18]. The transformation to sustainable economies having low-carbon production sources require provisions of affordable and secure energy for social development and economic growth [19]. The Paris Agreement has already proposed a target to transform the global economic structure in the upcoming decades by reducing the global temperature for conducive environmental habitation [20]. Therefore, it is essential to prioritize technological innovation into the policymaking of emissions mitigation.

The Association of Southeast Asian Nations (ASEAN) comprises of ten South Asian economies that aim to promote social, cultural and economic cooperation among the member countries. ASEAN came into existence in 1967, with the membership of ten countries including Malaysia, Indonesia, Brunei, Cambodia, Myanmar, Singapore, Philippines, Vietnam, Laos and Thailand. ASEAN region also faces a similar global issue of secure, affordable and sustainable energy [21]. According to an estimation, $8 \%$ of the total fossil fuel reserves are present in ASEAN countries. Due to excess utilization of fossil fuel production sources, the share of global greenhouse gas emissions will become double by 2040 [20].

In the above context, our study aimed to investigate the impact of economic openness and innovation on the environment of ASEAN member countries for 1990-2014. This study will answer the following main research questions: (1) Does economic openness such as FDI, trade openness, and economic growth harm the environment of the ASEAN region? (2) Does technology innovation improve the environmental quality of ASEAN countries? The novel aspect of this study is twofold; first, we investigate the impact of economic openness on the environment of ASEAN countries, and secondly, we have examined the role of technology innovation in mitigating the $\mathrm{CO}_{2}$ emissions. Previous studies have only considered the import- $\mathrm{CO}_{2}$ emissions, exports- $\mathrm{CO}_{2}$ emissions, Economic growth$\mathrm{CO}_{2}$ emissions, innovations- $\mathrm{CO}_{2}$ emissions etc. But we have analyzed the association among the overall economic openness, $\mathrm{CO}_{2}$ emissions and technology innovation in our study. Moreover, we have utilized different econometric models to have a new look into ASEAN countries. This study will assist governments and policy-makers in decision making regarding environmental sustainability.

We have organized the remaining part of the study as follows: Review of Literature section will thoroughly elaborate the association among economic openness, innovation and environment. Methodology and Model specification section will discuss the data and empirical techniques of the study. Discussion and Results section will thoroughly explain the findings of the study and elaborate the obtained results. Finally, Conclusion and policy recommendations section will conclude the study 
and provide useful policy recommendations for the governments and policy-makers.

\section{Literature Review}

The study explored the association among FDI, trade openness, economic growth, technological innovations, and carbon emissions. Numerous studies have already examined the inter-relationship among economic openness, innovations and $\mathrm{CO}_{2}$ emissions. We will review all aspects with the help of existing relevant evidence. The theoretical and empirical literature on the impact of economic openness on the emissions consists of mixed opinions, and it continued to be a debatable topic. For instance, the study about China, evaluates the impact of FDI and international trade on the $\mathrm{CO}_{2}$ emissions of Chinese provinces for 1997-2014. By employing the quantile regression approach, the study found negative and significant impacts of FDI and trade on $\mathrm{CO}_{2}$ emissions [22]. Similarly, another study examined the effects of FDI and economic growth on $\mathrm{CO}_{2}$ emissions in the case of Kuwait for 1980-2013. By employing the ARDL model, the study concluded that FDI and economic growth increase $\mathrm{CO}_{2}$ emissions [14]. Likewise, another study investigated the impact of trade openness, income and energy use on the $\mathrm{CO}_{2}$ emissions of selected emerging economies for 1971-2011. By employing the unit root test of ZivotAndrews, the bound co-integration techniques and the VECM Granger causality tests, the study found co-integration among the underlying variables. Additionally, the study found that trade openness, energy use and real income enhances $\mathrm{CO}_{2}$ emissions [23]. On the other hand, a study examined FDI-carbon emissions nexus in the case of Turkey for 1974-2013. The study found that FDI reduces $\mathrm{CO}_{2}$ emissions [24]. Similarly, another study about selected Asian countries, investigated the effects of FDI on $\mathrm{CO}_{2}$ emissions for 1982-2016 for five countries. The study found that FDI reduces $\mathrm{CO}_{2}$ emissions by enhancing environmental friendly technology and environmentally friendly management practices in China, India, Iran, Indonesia and South Africa [25]. On the contrary to that, a study analyzed the link among $\mathrm{CO}_{2}$ emissions, energy use, FDI and economic growth in the case of Vietnam for 1976-2009. The study employed the Granger causality test and cointegration test and found that there was a long-run equilibrium among the underlying variables. Moreover, two-way causalities were also observed between foreign direct investment- $\mathrm{CO}_{2}$ emissions and $\mathrm{CO}_{2}$ emissions-income. The study recommended FDI as an essential instrument for mitigating the effects of $\mathrm{CO}_{2}$ emissions through clean technology transfers [26]. An empirical study examined the relationship among trade openness, economic growth financial development, coal consumption and $\mathrm{CO}_{2}$ emissions in South Africa. By employing the ARDL bounds testing method, the results of the study reveal that trade significantly contributes to the improvement of the environment in South Africa [27]. Likewise, another study investigated the association among trade openness, $\mathrm{CO}_{2}$ emissions, GDP and energy consumption in 25 OECD countries. The results obtained from panel FMOLS and DOLS confirmed the effectiveness of trade for mitigating $\mathrm{CO}_{2}$ emissions in OECD countries [28]. Moreover, another study analyzed the association among trade, real income, population, energy consumption and $\mathrm{CO}_{2}$ emissions in 82 emerging economies for 1880-2012. By employing several empirical approaches, such as mean group (MG) using various mean group (MG) and crosscorrelated and augmented method, the results reveal that increase in trade results in decline in $\mathrm{CO}_{2}$ emissions. Also, openness enhances environmental quality [29]. The study about Common Wealth of Independent States (CIPS) investigated the causal link and longrun association among $\mathrm{CO}_{2}$ emissions, trade openness, economic growth and energy consumption in a panel of Common Wealth of Independent States (CIPS). The results found a unidirectional short-run causality from trade openness to $\mathrm{CO}_{2}$ emissions [30]. Another study found that trade openness, economic growth, financial development and energy consumption determine $\mathrm{CO}_{2}$ emissions. Moreover, there was unidirectional causality from trade openness to $\mathrm{CO}_{2}$ emissions. The study confirmed the validity of the KKC hypothesis for Turkey in short-run as well as long-run [31].

A study about Pakistan examined the nexus among economic growth, energy consumption and $\mathrm{CO}_{2}$ emissions by using ARDL method. The time-series data of 1965-2015 shows a positive relationship between economic growth and $\mathrm{CO}_{2}$ emissions in Pakistan both in the short and long-run [32]. Similarly, another study examined the association between economic growth and $\mathrm{CO}_{2}$ emissions in the presence of other variables such as financial development, international trade and tourism expenditure. The results of ARDL estimations show that economic growth enhances $\mathrm{CO}_{2}$ emissions in Greece for 1970-2014 [33]. Likewise, a study examined the relationship between economic growth and $\mathrm{CO}_{2}$ emissions for a panel of 31 emerging economies. The threshold framework model shows that there is a positive impact of economic growth on $\mathrm{CO}_{2}$ emissions in a regime with high growth while a negative impact has been detected in case of low growth regimes. Moreover, the study doesn't support the Environmental Kuznets Curve hypothesis [34]. Another study investigates the connection between per capita growth and the environment by using panel data in non-OECD economies for 1971-1997. The results of this study also do not provide support for the environmental Kuznets curve. Moreover, the findings came up with two-income regimes, namely low-income regime and middle to highincome regime. The emissions rise with the increase of economic growth in low-income regime while a decrease in the middle to the high-income regime [35]. The study about BRICS investigates the relationship among economic growth, energy use and carbon 
dioxide in five BRICS countries for 1992 to 2016. The results of the STIRPAT model indicate that economic growth and energy use increase $\mathrm{CO}_{2}$ emissions in five BRICS countries [36]. Similarly, an ARDL study investigated the connection among economic growth, energy consumption and $\mathrm{CO}_{2}$ emissions in Malaysia for 1975-2014. The findings from ARDL estimations show that $\mathrm{CO}_{2}$ emissions do not affect economic growth and energy consumption, but economic growth and energy consumption have a positive impact on $\mathrm{CO}_{2}$ emissions in the case of Malaysia [37]. Moreover, another study analyzed the effects of economic growth on the environment along with other variables of the study in 34 countries of Sub-Saharan Africa for 1995-2015. By using GMM techniques, the results of the study indicate that there is an inverted U-shaped connection between economic growth and $\mathrm{CO}_{2}$ emissions. Furthermore, the findings confirm the presence of Environmental Kuznet Curve in case of low and middle income countries of Sub-Saharan Africa [38].

Foreign firms have emerged as environmentally friendly due to their efficient production sources in the countries where environmental regulations are usually weak. The foreign firms often depend on advanced technology, and they have a spillover effect on the domestic firms in the host economy [39]. An empirical study on G-6 countries analyzed the relationship between innovation and environment for 2004-2016. By utilizing firm-level data, the authors found that innovation and $\mathrm{CO}_{2}$ emissions are inversely proportional to each other [40]. Another study analyzed the impact of innovation on $\mathrm{CO}_{2}$ emissions in Malaysia from 1971 to 2013. The study found that technological innovation reduces $\mathrm{CO}_{2}$ emissions in the short run. The study suggests that innovation boosts economic growth as well as environmental sustainability [41]. An empirical study analyzed the impact of technological innovation on $\mathrm{CO}_{2}$ emissions of China by utilizing the STIRPAT model. The study found that innovations reduce $\mathrm{CO}_{2}$ emissions in China [42]. Another study investigated the nexus between innovations and $\mathrm{CO}_{2}$ emissions of 18 developed and developing countries for 1990 to 2016. The study employed Dickey-Fuller (CADF) and Westerlund cointegration techniques to observe co-integration among variables. The findings of FMOLS and DOLS estimations show that technological innovations mitigate $\mathrm{CO}_{2}$ emissions in $\mathrm{G} 6$ countries but increase emissions in BRICS and MENA economies [43]. A study about China depicted that innovations positively affect the environment in China by reducing $\mathrm{CO}_{2}$ emissions [44]. Hence, a vast number of studies show that innovations mitigate the deteriorating effects of the environment $[45,46]$.

Considering the lack of significant studies in the existing literature, this study aims to analyze the impact of economic openness and innovations on ASEAN countries. Therefore, the main objective of this study to investigate the environmental effects of FDI, trade openness, economic growth and innovations on the
ASEAN region to overcome the gaps in the previous studies.

\section{Methodology and Model Specification}

In this section, we will discuss our estimation techniques and data of the study. The basic model of our research study is as follows.

$$
C O_{2}=f\left(F D I_{i t}, T O_{i t}, G D P_{i t}, E U_{i t}, P A T_{i t}, T M_{i t}\right)(1)
$$

Where FDI indicates foreign direct investment; TO represents trade openness; GDP shows economic growth; EU illustrates energy use; PAT specifies patents and TM is for trademark. In our model, i shows countries and t means time. We have taken data of FDI, GDP, EU, PAT and TM from the World Bank database. The data for trade openness has been taken from UNTCAD database. The detailed description and definitions of variables are presented in Table 1. For convenience, we transform the variables into log form. Hence, we can write the above equation as follows:

$$
\begin{aligned}
& \operatorname{lnCO} O_{i t}=\alpha_{0}+\beta_{1} F D I_{i t}+\beta_{2} T O_{i t}+\beta_{3} G D P_{i t} \\
& +\beta_{4} E U_{i t}+\beta_{5} P A T_{i t}+\beta_{6} T M_{i t}+\mu_{i t}
\end{aligned}
$$

...where $\alpha_{0}$ and $\mu_{i t}$ represent constant term and the error term, respectively; $\beta_{1}, \beta_{2}, \beta_{3}$ and $\beta_{4}$ stand for undermined coefficients.

$$
\begin{gathered}
\ln F D I_{i t}=\alpha_{0}+\beta_{1} C O_{2 i t}+\beta_{2} T O_{i t}+\beta_{3} G D P_{i t} \\
+\beta_{4} E U_{i t}+\beta_{5} P A T_{i t}+\beta_{6} T M_{i t}+\mu_{i t} \\
\ln T O_{i t}=\alpha_{0}+\beta_{1} C O_{2 i t}+\beta_{2} F D I_{i t}+\beta_{3} G D P_{i t} \\
+\beta_{4} E U_{i t}+\beta_{5} P A T_{i t}+\beta_{6} T M_{i t}+\mu_{i t} \\
\ln G D P_{i t}=\alpha_{0}+\beta_{1} C O_{2 i t}+\beta_{2} F D I_{i t}+\beta_{3} T O_{i t} \\
+\beta_{4} E U_{i t}+\beta_{5} P A T_{i t}+\beta_{6} T M_{i t}+\mu_{i t} \\
\ln E U_{i t}=\alpha_{0}+\beta_{1} C O_{2 i t}+\beta_{2} F D I_{i t}+\beta_{3} T O_{i t} \\
+\beta_{4} G D P_{i t}+\beta_{5} P A T_{i t}+\beta_{6} T M_{i t}+\mu_{i t} \\
\ln P A T_{i t}=\alpha_{0}+\beta_{1} C O_{2 i t}+\beta_{2} F D I_{i t}+\beta_{3} T O_{i t} \\
+\beta_{4} G D P_{i t}+\beta_{5} E U_{i t}+\beta_{6} T M_{i t}+\mu_{i t} \\
\ln T M_{i t}=\alpha_{0}+\beta_{1} C O_{2 i t}+\beta_{2} F D I_{i t}+\beta_{3} T O_{i t} \\
+\beta_{4} G D P_{i t}+\beta_{5} E U_{i t}+\beta_{6} P A T_{i t}+\mu_{i t}
\end{gathered}
$$

\section{Descriptive Statistics}

In our study, we have collected data from six ASEAN member countries such as Indonesia, Malaysia, Philippine, Singapore, Thailand and Vietnam for 1990-2014. The data has been taken from the 
World Bank and UNTCAD databases. Additionally, we have provided a description of the variables in Table 1 and the data description in Table 2. According to the availability of the data, we have chosen our study period. The maximum value of patents in ASEAN countries is 12581, with a mean value of 4453.307 across our panel. Likewise, the maximum value of FDI was calculated at $26.3266 \%$ with 5.212923 mean value. The trade openness varied between 596753.1 maximum and 119724.8 minimum with the average value 119724.8. The maximum value of per capita GDP accounted for 52994.04 with an average of 8892.384 . The maximum values of trademark and energy use accounted for 2.14512 and 7370.653 with average mean values of 0.9579905 and 1717.105 . Finally, the values of $\mathrm{CO}_{2}$ varied between 18.04087 maximum value and .3029989 minimum value with an average value of 0.958. Moreover, Fig. 1 presents the scattered plotting
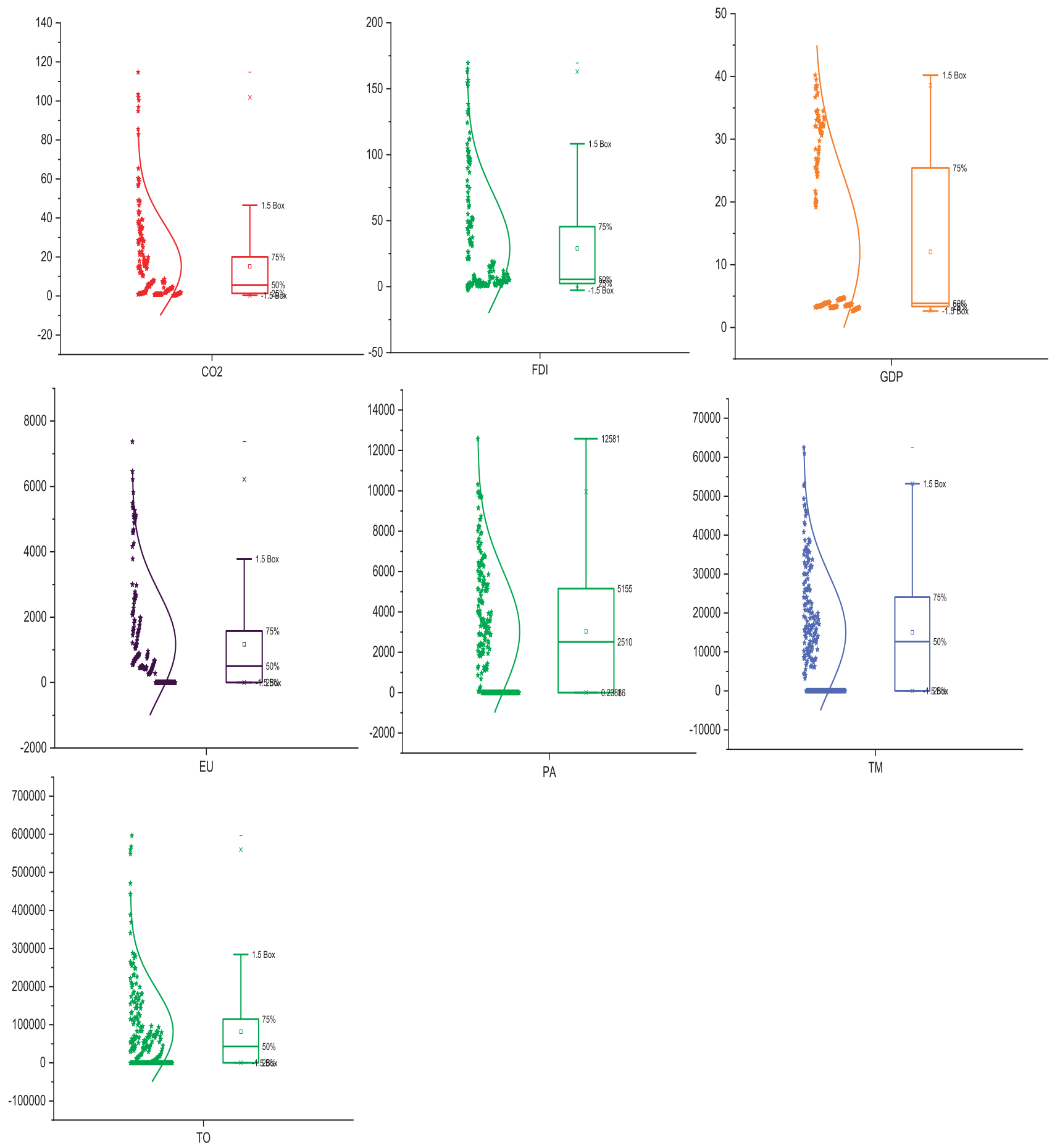

Fig. 1. Box chart of the seven variables. Note: The square represents the average value, the horizontal bar in the box represents the median, the dots represent the minimum/maximum value, and the upper and lower edges of the box represent the $75^{\text {th }}$ and $25^{\text {th }}$ percentage points, respectively. 
Table 1. Variables, definitions, and measures for the period 1990-2014.

\begin{tabular}{|c|c|c|c|}
\hline Variable & Unit of measurement & Definition & Source \\
\hline $\mathrm{CO}_{2}$ emissions & Tons & $\begin{array}{c}\text { "Carbon dioxide emissions are those stemming from } \\
\text { the burning of fossil fuels and the manufacture of } \\
\text { cement." }\end{array}$ & WDI \\
\hline Foreign direct investment & Percentage & Foreign direct investment, net inflows (\% of GDP) & WDI \\
\hline Patent applications (PA) & Numbers & $\begin{array}{l}\text { "Sum of total residents patent applications and non- } \\
\text { residents patent applications." }\end{array}$ & WDI \\
\hline Trade openness (TO) & Constant US dollars & $\begin{array}{l}\text { "Total trade of goods and services measured in mil- } \\
\text { lions of constant US dollars." }\end{array}$ & UNTCAD \\
\hline GDP per capita (GDP) & Constant 2010 US dollars & $\begin{array}{c}\text { "Gross domestic product divided by midyear popula- } \\
\text { tion." }\end{array}$ & WDI \\
\hline Trademarks & Numbers & "Total number of trademark applications." & WDI \\
\hline Energy Use & $\begin{array}{l}\mathrm{kg} \text { of oil equivalent per } \\
\text { capita (kgoe) }\end{array}$ & $\begin{array}{l}\text { "Energy use refers to use of primary energy before } \\
\text { transformation to other end-use fuels, which is equal } \\
\text { to indigenous production plus imports and stock } \\
\text { changes, minus exports and fuels supplied to ships } \\
\text { and aircraft engaged in international transport." }\end{array}$ & WDI \\
\hline
\end{tabular}

Table 2. Descriptive statistics.

\begin{tabular}{|c|c|c|c|c|c|c|}
\hline Variable & & Mean & Std.Dev. & Min & Max & Observations \\
\hline \multirow{3}{*}{$P A$} & Overall & 4453.307 & 2592.951 & 62 & 12581 & $\mathrm{~N}=150$ \\
\hline & Between & & 2198.484 & 1786.56 & 8132.28 & $\mathrm{n}=6$ \\
\hline & Within & & 1633.581 & -1421.973 & 8902.027 & $\mathrm{~T}=25$ \\
\hline \multirow{3}{*}{$F D I$} & Overall & 5.212923 & 5.727271 & -2.75744 & 26.3266 & $\mathrm{~N}=150$ \\
\hline & Between & & 5.368549 & 1.126316 & 15.55837 & $\mathrm{n}=6$ \\
\hline & Within & & 2.93644 & -6.116918 & 15.98116 & $\mathrm{~T}=25$ \\
\hline \multirow{3}{*}{ TO } & Overall & 119724.8 & 118540.8 & 1913 & 596753.1 & $\mathrm{~N}=150$ \\
\hline & Between & & 85247.62 & 38835.28 & 271128.8 & $\mathrm{n}=6$ \\
\hline & Within & & 89192.59 & -83914.54 & 445349.1 & $\mathrm{~T}=25$ \\
\hline \multirow{3}{*}{$G D P$} & Overall & 8892.384 & 13202.34 & 433.2839 & 52994.04 & $\mathrm{~N}=150$ \\
\hline & Between & & 13803.47 & 916.2912 & 36677.83 & $\mathrm{n}=6$ \\
\hline & Within & & 3802.147 & -5213.539 & 25208.6 & $\mathrm{~T}=25$ \\
\hline \multirow{3}{*}{$T M$} & Overall & 0.9579905 & 0.4943999 & 0.00006 & 2.14512 & $\mathrm{~N}=150$ \\
\hline & Between & & 0.3735512 & 0.5622042 & 1.481597 & $\mathrm{n}=6$ \\
\hline & Within & & 0.3627828 & -0.5235468 & 1.621513 & $\mathrm{~T}=25$ \\
\hline \multirow{3}{*}{$E U$} & Overall & 1717.105 & 1700.085 & 260.791 & 7370.653 & $\mathrm{~N}=150$ \\
\hline & Between & & 1804.554 & 425.5069 & 5137.688 & $\mathrm{n}=6$ \\
\hline & Within & & 397.9891 & 362.1373 & 3950.07 & $\mathrm{~T}=25$ \\
\hline \multirow{3}{*}{$\mathrm{CO}_{2}$} & Overall & 3.947879 & 3.995822 & .3029989 & 18.04087 & $\mathrm{~N}=150$ \\
\hline & Between & & 4.019567 & .8634235 & 11.10329 & $\mathrm{n}=6$ \\
\hline & Within & & 1.553102 & -2.8128 & 10.88547 & $\mathrm{~T}=25$ \\
\hline
\end{tabular}

Note: Std. Dev. indicates standard deviation; Max and Min show maximum and minimum values, respectively. 
of FDI, trade openness and GDP, energy use, patents and trademarks of ASEAN countries.

\section{Estimation Techniques}

We present a systematic procedure for the empirical estimation of equation (2). (i) We employed the Pesaran $\mathrm{CD}$ test for examining the cross-sectional dependence among the underlying variables in our model. (ii) For the unit root test, we have utilized the Pesaran CIPS test. (iii) For observing co-integration among the variables, Pedroni-cointegration and Kao-cointegration tests have employed. (iv) We have used FMOLS and DOLS estimation techniques to analyze the determinants of $\mathrm{CO}_{2}$ emissions. (v) We have employed Dumitrescu and Hurlin panel causality test to examine the directions of causalities.

\section{Cross-Sectional Dependence}

To avoid any erroneous results, there should be cross-sectional dependence in the model [47, 48]. Therefore, in this study, we have used the BreuschPagan Lagrange multiplier (LM) test to check for crosssectional dependence in our panel.

\section{Panel Unit Root Test}

After confirming cross-sectional dependence in the panel, the unit root tests of the first generation such as Im, Pesaran, and Shin (IPS) Augmented Dickey-Fuller (ADF), Phillips- Perron (PP) seem to be invalid. Hence, we choose second-generation unit root tests, i.e. Pesaran Augmented Dickey-Fuller (CADF), and the Pesaran cross-sectionally Augmented Im Pesaran and Shin (IPS) tests. Pesaran and Shin developed these tests [49].

\section{Panel Co-Integration Test}

We have used Pedroni co-integration test for detecting cointegration in our panel. Pedroni developed this cointegration test [50]. The Kao panel cointegration test has also been employed to avoid any prejudiced results [51]. The panel-specific autoregressive (AR) test statistic and the same- specific autoregressive (AR) tests statistic have been used for cross-sectional dependencies of panel co-integration test.

\section{Panel Causality Test}

We have employed the D-H panel causality test in our study, which was introduced by Dumitrescu and Hurlin [52].

\section{Results and Discussion}

\section{Outcomes of Cross-Sectional Dependence}

We have presented the results of cross-sectional dependence test in Table 3. The results show that there is a strong cross-sectional dependence among the underlying variables of the study. The study rejected the null hypothesis at $1 \%$ significance level and accepted the alternate hypothesis.

\section{Outcomes of Panel Unit Root Test}

We have used the Pesaran (CIPS) unit root test to confirm the stationarity level of the variables. We have presented the outcomes of the Pesaran (CIPS) unit root test in Table 4. The results show that the null hypothesis is rejected at level, with intercept, intercept and trend. At first difference, stationarity was observed at $1 \%$ level for intercept and intercept and trend. It depicts that the underlying variables are integrated at the order I (1). Therefore, it is justified that we can investigate the long-run relationship.

We have double checked the stationarity properties of the underlying variables by using Harris-Tzavalis unit-root test, Levin, Lin, and Chu (2002) and Im, Pesaran, and Shin (2003) unit root test. The outcomes of the unit root tests are presented in Table 5. According

Table 3. Estimation of cross-sectional dependence.

\begin{tabular}{|c|c|c|c|c|}
\hline Variable & $\mathrm{CD}_{\text {Pesaran }}$ & $\mathrm{LM}_{\text {Breusch-Pagan }}$ & $\mathrm{LM}_{\text {Pesaran scaled }}$ & $\mathrm{LM}_{\text {Bias-corrected scaled }}$ \\
\hline$P A$ & $11.5083^{* * *}$ & $138.8005^{* * *}$ & $22.6027^{* * *}$ & $22.4777 * * *$ \\
\hline$F D I$ & $14.377^{* * *}$ & $21.8714^{*}$ & $1.2546^{* *}$ & $1.1296^{* *}$ \\
\hline$T O$ & $18.5352^{* * *}$ & $343.9598^{* * *}$ & $60.0597 * * *$ & $59.9347 * * *$ \\
\hline$G D P$ & $18.8778^{* * *}$ & $356.4323 * * *$ & $62.3368^{* * *}$ & $62.2118^{* * *}$ \\
\hline$T M$ & $18.737 * * *$ & $279.9518^{* * *}$ & $48.3734 * * *$ & $48.2483^{* * *}$ \\
\hline$E U$ & $4.8123^{* * *}$ & $145.4204 * * *$ & $23.8114 * * *$ & $23.6862^{* * *}$ \\
\hline$C O_{2}$ & $6.2522^{* * *}$ & $209.5754 * * *$ & $35.5245^{* * *}$ & $35.3995^{* * *}$ \\
\hline
\end{tabular}

Note: $* * *$ and $* * *$ indicate significance at the $10 \%, 5 \%$ and $1 \%$ level respectively, Null hypothesis $=$ no cross-sectional dependence. 
Table 4. Pesaran CIPS Panel unit root test.

\begin{tabular}{|c|c|c|c|c|c|}
\hline \multirow{2}{*}{ Variable } & \multicolumn{2}{|c|}{ Level } & \multicolumn{2}{c|}{ First difference } & \multirow{2}{*}{ Integration order } \\
\cline { 2 - 6 } & Constant & Constant \& trend & Constant & Constant \& trend & \\
\hline PA & -2.718 & -2.944 & -5.128 & -5.190 & $\mathrm{I}(1)$ \\
\hline FDI & -2.433 & -2.931 & -5.261 & -5.224 & $\mathrm{I}(1)$ \\
\hline TO & -0.606 & -2.731 & -3.717 & -3.319 & $\mathrm{I}(1)$ \\
\hline GDP & -2.337 & -2.595 & -3.123 & -3.355 & $\mathrm{I}(1)$ \\
\hline TM & -2.086 & -2.224 & -4.407 & -4.504 & $\mathrm{I}(1)$ \\
\hline EU & -1.652 & -2.567 & -4.216 & -4.031 & $\mathrm{I}(1)$ \\
\hline $\mathrm{CO}_{2}$ & -0.567 & -3.417 & -4.418 & -4.360 & $\mathrm{I}(1)$ \\
\hline
\end{tabular}

Note: critical values at $10 \%, 5 \%$ and $1 \%$ including constant; $-2.21,-2.33,-2.57$; and including constant $\&$ trend are; $-2.73,-2.86$, and -3.1 respectively.

Table 5. Panel unit root tests.

\begin{tabular}{|c|c|c|c|c|}
\hline \multirow{2}{*}{ Harris-Tzavalis unit-root test } & \multicolumn{2}{|c|}{ Level } & \multicolumn{2}{|c|}{ First difference } \\
\hline & Constant & Constant \& trend & Constant & Constant \& trend \\
\hline PA & $0.5775^{x}$ & $0.1749^{x}$ & $-0.3056^{x}$ & $-0.3026^{x}$ \\
\hline FDI & $0.3187^{x}$ & $0.0897^{x}$ & $-0.3555^{x}$ & $-0.3536^{x}$ \\
\hline TO & 1.0258 & 0.8045 & $-0.0447^{x}$ & $0.0573^{x}$ \\
\hline GDP & 1.0043 & $0.5704^{y}$ & $-0.0234^{\mathrm{x}}$ & $0.3061^{\mathrm{x}}$ \\
\hline TM & 0.9357 & $0.4005^{\mathrm{x}}$ & $-0.3171^{x}$ & $-0.2977^{x}$ \\
\hline EU & $0.6160^{x}$ & $0.3945^{x}$ & $-0.2028^{x}$ & $-0.1952^{x}$ \\
\hline $\mathrm{CO}_{2}$ & $0.7877^{y}$ & $0.5247^{\mathrm{x}}$ & $-0.1734^{x}$ & $-0.1564^{x}$ \\
\hline \multicolumn{5}{|l|}{ Levin-Lin-Chu (LLC) unit-root test } \\
\hline PA & 0.1358 & $-2.8362^{x}$ & $-8.3620^{\mathrm{x}}$ & $-6.9950^{x}$ \\
\hline FDI & $-2.6579^{y}$ & $-2.1673^{x}$ & $-7.2582^{x}$ & $-5.7144^{x}$ \\
\hline TO & 4.1025 & 0.9051 & $-4.4561^{x}$ & $-4.4973^{x}$ \\
\hline GDP & 4.1357 & -0.0078 & $-3.4799^{x}$ & $-4.6798^{x}$ \\
\hline $\mathrm{TM}$ & 1.3706 & -0.5413 & $-4.7439^{x}$ & $-3.9114^{x}$ \\
\hline EU & -0.9283 & -0.3821 & $-2.6454^{x}$ & -0.9228 \\
\hline $\mathrm{CO}_{2}$ & -0.2671 & $-1.9109^{x}$ & $-6.3065^{x}$ & $-4.8530^{x}$ \\
\hline \multicolumn{5}{|l|}{ Im-Pesaran-Shin (IPS) unit-root test } \\
\hline PA & -0.0741 & $-3.2432^{x}$ & $-6.4837^{x}$ & $-6.5434^{x}$ \\
\hline FDI & $-3.1180^{x}$ & $-3.9248^{x}$ & $-6.9535^{x}$ & $-6.9746^{x}$ \\
\hline TO & 6.7815 & -0.1072 & $-5.5602^{x}$ & $-6.3038^{x}$ \\
\hline GDP & 8.7310 & 0.7089 & $-5.3207^{x}$ & $-5.3207^{x}$ \\
\hline $\mathrm{TM}$ & 3.8071 & $-1.6088^{\mathrm{z}}$ & $-5.7485^{x}$ & $-5.9231^{x}$ \\
\hline EU & 0.2265 & $-1.9810^{y}$ & $-4.4858^{x}$ & $-4.2223^{x}$ \\
\hline $\mathrm{CO}_{2}$ & 1.0898 & $-2.6784^{x}$ & $-5.9900^{x}$ & $-6.0717^{x}$ \\
\hline
\end{tabular}

Note: $x, y$, and $z$ Show the level of significance at $1 \%, 5 \%$, and $10 \%$. 
Table 6. Panel co-integration results.

\begin{tabular}{|c|c|c|}
\hline $\begin{array}{c}\text { Ho: No cointegration } \\
\text { Ha: All panels are cointegrated }\end{array}$ & Statistic & p-value(s) \\
\hline \multicolumn{3}{|c|}{ Pedroni-cointegration } \\
\hline Modified Phillips-Perron t-statistics & 2.9149 & 0.0018 \\
\hline Phillips-Perron t-statistics & -4.1486 & 0.0000 \\
\hline Augmented Dickey-Fuller t-statistics & -2.6625 & 0.0039 \\
\hline \multicolumn{3}{|c|}{ Kao-cointegration } \\
\hline $\begin{array}{l}\text { Modified Dickey-Fuller (MDF) } \\
\text { t-statistics }\end{array}$ & -1.8024 & 0.0357 \\
\hline Dickey-Fuller (DF) t-statistics & -2.2264 & 0.0130 \\
\hline $\begin{array}{l}\text { Augmented Dickey-Fuller (ADF) } \\
\text { t-statistics }\end{array}$ & -1.8650 & 0.0311 \\
\hline $\begin{array}{l}\text { Unadjusted modified Dickey-Fuller } \\
\text { (UMDF) t-statistics }\end{array}$ & -7.4667 & 0.0000 \\
\hline $\begin{array}{c}\text { Unadjusted Dickey-Fuller (UDF) } \\
\text { t-statistics }\end{array}$ & -4.4128 & 0.0000 \\
\hline
\end{tabular}

Note: Ho is the null hypothesis, Ha is an alternative hypothesis and significance level at $5 \%$ and $1 \%$.

to the obtained results, the null hypothesis has been rejected at $1 \%$ level for intercept and intercept and trend, as shown in Table 5. The underlying variables in ASEAN panel are integrated at the order I (1); hence it justifies the investigation of long-run relationship.

\section{Outcomes of Panel Co-Integration Test}

We have utilized Pedroni 2004 and Kao 1999 to find the co-integration among the variables, as shown in Table 6. According to Pedroni test, the variables of the study seemed to be significant. It implies that there is co-integration among the variables. Furthermore, the outcomes of Kao test also show co-integration among the underlying variables of our model. Hence, the results of Pedroni and Kao tests justified investigating the long-run relationship. Consequently, FMOLS and DOLS techniques are used to determine the long-run relationship.

\section{Westerlund Panel Cointegration Tests}

Due to the presence of cross-sectional dependence among the variables, we have utilized Westerlund, 2007 for the cointegration test. The outcomes of Westerlund panel cointegration test shows that there is cointegration among the variables in the panel of ASEAN countries. The obtained results imply that a long-run relationship exists among the underlying variables. The Westerlund, 2007 cointegration account for cross-sectional dependence because it contains bootstrap properties that eliminate such problems as the correlation among the units. The Gt, Ga (betweenand among-group cross-sectional units) and $\mathrm{Pt}, \mathrm{Pa}$
Table 7. Westerlund ECM panel cointegration tests.

\begin{tabular}{|c|c|c|}
\hline $\begin{array}{c}\text { Ho: No cointegration } \\
\text { Statistic }\end{array}$ & Value & Robust p-value \\
\hline $\mathrm{Gt}$ & -2.274 & 0.089 \\
\hline $\mathrm{Ga}$ & -3.194 & 0.065 \\
\hline $\mathrm{Pt}$ & -3.536 & 0.046 \\
\hline $\mathrm{Pa}$ & -3.780 & 0.075 \\
\hline
\end{tabular}

(between and among the whole panel) statistics with $\mathrm{p}$ values and robust $p$ values show a rejection of the null hypothesis of no cointegration. This means that there is cointegration, evidence of a long-run relationship among the series.

\section{Panel FMOLS and DOLS Results}

We have presented the results of FMOLS and DOLS estimations in Table 8. The estimated results of FMOLS and DOLS techniques are almost similar to each other. The estimations of long-run coefficients depict that energy use significantly increases $\mathrm{CO}_{2}$ emissions at $1 \%$ significance level. A unit increase in energy use results in an increase of $63 \%$ to $54 \% \mathrm{CO}_{2}$ emissions. Numerous studies have identified energy consumption as a significant source of $\mathrm{CO}_{2}$ emissions [53]. Therefore, the findings are parallel with the results of mainstream literature. Trade openness has a positive and significant impact on $\mathrm{CO}_{2}$ emissions at $10 \%$ significance level. It implies that a unit increase in trade openness rises $27 \%$ to $33 \% \mathrm{CO}_{2}$ emissions. Rasoulinezhad and Saboori [30] and Sun et al. [2] also found similar results. FDI negatively and significantly affects the $\mathrm{CO}_{2}$ emissions at $1 \%$ significance level. A unit increase of FDI depresses $3 \%$ to $4 \% \mathrm{CO}_{2}$ emissions in the ASEAN region. Our results established that FDI has a positive impact on environmental quality. Sarkodie and Strezov [25] and many other mainstream studies have also got the same results. Likewise, there was a negative and significant association between GDP and $\mathrm{CO}_{2}$ emissions at a 5\% level of significance. We found that a unit increase in GDP decreased by $74 \%$ to $90 \%$ emissions. The findings

Table 8. Results of FMOLS and DOLS estimation.

\begin{tabular}{|c|c|c|c|c|}
\hline & \multicolumn{2}{|c|}{ FMOLS } & \multicolumn{2}{c|}{ DOLS } \\
\hline & Coefficient & P value & Coefficient & P value \\
\hline LnEU & 0.630213 & 0 & 0.543102 & 0 \\
\hline LnFDI & -0.033333 & 0 & -0.046662 & 0 \\
\hline LnGDP & -0.903357 & 0.032 & -0.745907 & 0.048 \\
\hline LnPA & -0.235603 & 0 & -0.330612 & 0 \\
\hline LnTM & -0.138218 & 0.214 & -0.420812 & 0.431 \\
\hline LnTO & 0.272336 & 0.066 & 0.334011 & 0.076 \\
\hline
\end{tabular}


Table 9. Results of Dumitrescu Hurlin panel causality test.

\begin{tabular}{|c|c|c|c|}
\hline Null Hypothesis: & W-Stat. & Zbar-Stat. & Prob. \\
\hline $\operatorname{LnEU} \neq \mathrm{LnCO}_{2}$ & 2.43153 & 0.17429 & 0.0616 \\
\hline $\mathrm{LnCO}_{2} \neq \mathrm{LnEU}$ & 1.43355 & -0.78389 & 0.0331 \\
\hline $\mathrm{LnFDI} \neq \mathrm{LnCO}_{2}$ & 1.08968 & -1.11025 & 0.0569 \\
\hline $\mathrm{LnCO}_{2} \neq \mathrm{LnFDI}$ & 2.51784 & 0.23434 & 0.0147 \\
\hline $\mathrm{LnGDP} \neq \mathrm{LnCO}_{2}$ & 3.97237 & 1.65366 & 0.0982 \\
\hline $\mathrm{LnCO}_{2} \neq \mathrm{Ln} G D P$ & 2.21630 & -0.03236 & 0.0742 \\
\hline $\operatorname{LnPA} \neq \mathrm{LnCO}_{2}$ & 2.01911 & -0.22168 & 0.0246 \\
\hline $\mathrm{LnCO} \neq \mathrm{LnPA}$ & 5.77506 & 3.38444 & 0.0007 \\
\hline $\mathrm{LnTM} \neq \mathrm{LnCO} \mathrm{C}_{2}$ & 1.91559 & -0.32107 & 0.7482 \\
\hline $\mathrm{LnCO}_{2} \neq \mathrm{LnTM}$ & 4.13194 & 1.80687 & 0.0708 \\
\hline $\mathrm{LnTO} \neq \mathrm{LnCO}_{2}$ & 5.26483 & 2.89457 & 0.0038 \\
\hline $\mathrm{LnCO}_{2} \neq \mathrm{LnTO}$ & 1.56641 & -0.65632 & 0.5116 \\
\hline$L n F D I \neq L n E U$ & 2.40759 & 0.13054 & 0.8961 \\
\hline$L n E U \neq L n F D I$ & 3.47040 & 1.13115 & 0.2580 \\
\hline$L n G D P \neq L n E U$ & 2.25481 & 0.00462 & 0.9963 \\
\hline$L n E U \neq L n G D P$ & 2.86684 & 0.59224 & 0.5537 \\
\hline $\operatorname{LnPA} \neq \operatorname{LnEU}$ & 1.22816 & -0.98108 & 0.3266 \\
\hline$L n E U \neq L n P A$ & 5.72278 & 3.33425 & 0.0009 \\
\hline $\operatorname{Ln} T M \neq L n E U$ & 1.16306 & -1.04358 & 0.2967 \\
\hline$L n E U \neq L n T M$ & 4.79436 & 2.44287 & 0.0146 \\
\hline$L n T O \neq L n E U$ & 2.01603 & -0.22464 & 0.8223 \\
\hline $\operatorname{LnEU} \neq \operatorname{LnTO}$ & 2.92920 & 0.65211 & 0.5143 \\
\hline
\end{tabular}

are opposite to the majority of the studies but similar to the results of Fang et al. [7]. Moreover, patents negatively and significantly affects the $\mathrm{CO}_{2}$ emissions at $1 \%$ significance level, implies that a unit increase in patents decreases by $23 \%$ to $33 \% \mathrm{CO}_{2}$ emissions in ASEAN countries. Our results are similar to Choi and Han [54] and Dinda [46].

\section{Results of Dumitrescu-Hurlin Causality Test}

To check the causality among the underlying variables of the study, we have used Dumitrescu-Hurlin causality test. Table 9 depicts the causal relationship among the variables for the panel of BRICS countries. The results show that there was a bidirectional causality from energy use, FDI, GDP and patents to $\mathrm{CO}_{2}$ emissions. There was also a bidirectional causality from GDP to FDI. A unidirectional causality was detected from $\mathrm{CO}_{2}$ emissions, energy use and FDI to trademark. Moreover, one-way causalities were detected from trade openness to $\mathrm{CO}_{2}$, energy use to patents and patents to FDI. Various other studies such as Intisar et al. [55] and Le and Van [56] have also used Dumitrescu-

\begin{tabular}{|c|c|c|c|}
\hline Null Hypothesis: & W-Stat. & Zbar-Stat. & Prob. \\
\hline$L n G D P \neq L n F D I$ & 5.12115 & 2.68530 & 0.0072 \\
\hline$L n F D I \neq L n G D P$ & 4.17546 & 1.79495 & 0.0727 \\
\hline$L n P A \neq L n F D I$ & 5.45761 & 3.00207 & 0.0027 \\
\hline$L n F D I \neq L n P A$ & 1.63924 & -0.59285 & 0.5533 \\
\hline$L n T M \neq L n F D I$ & 3.93833 & 1.57170 & 0.1160 \\
\hline$L n F D I \neq L n T M$ & 4.94245 & 2.51706 & 0.0118 \\
\hline$L n T O \neq L n F D I$ & 3.64472 & 1.29527 & 0.1952 \\
\hline$L n F D I \neq L n T O$ & 3.62505 & 1.27675 & 0.2017 \\
\hline$L n P A \neq \operatorname{Ln} G D P$ & 1.60491 & -0.61935 & 0.5357 \\
\hline $\operatorname{Ln} G D P \neq \operatorname{Ln} P A$ & 8.02273 & 5.54245 & 3.E-08 \\
\hline $\operatorname{LnTM} \neq \operatorname{Ln} G D P$ & 7.79529 & 5.32408 & 1.E-07 \\
\hline $\operatorname{LnGDP} \neq \operatorname{LnTM}$ & 10.5833 & 8.00089 & 1.E-15 \\
\hline$L n T O \neq \operatorname{LnGDP}$ & 2.81900 & 0.54630 & 0.5849 \\
\hline$L n G D P \neq L n T O$ & 3.62010 & 1.31544 & 0.1884 \\
\hline $\operatorname{Ln} T M \neq \operatorname{Ln} P A$ & 7.35290 & 4.89934 & 1.E-06 \\
\hline$L n P A \neq L n T M$ & 3.40743 & 1.11126 & 0.2665 \\
\hline $\operatorname{Ln} T O \neq \operatorname{Ln} P A$ & 11.1174 & 8.51368 & 0.0000 \\
\hline$L n P A \neq L n T O$ & 1.97322 & -0.26574 & 0.7904 \\
\hline $\operatorname{LnTO} \neq$ LnTM & 5.45765 & 3.07970 & 0.0021 \\
\hline $\mathrm{LnTM} \neq \mathrm{LnTO}$ & 4.50192 & 2.16209 & 0.0306 \\
\hline
\end{tabular}

Note: The Dumitrescu Hurlin test is estimated with 3 lag and Zbar-statistics, $\operatorname{LnX} \neq \mathrm{LnY}$ suggests that $\mathrm{Ln} \mathrm{X}$ does not homogeneously cause $\mathrm{LnY}$

Hurlin causality test to find causalities among the variables.

\section{Conclusion and Recommendations}

\section{Conclusion}

We have investigated the impact of economic openness and innovations on the environment of ASEAN for 1990-2014. We have used the Pesaran CD test to examine cross-sectional dependence and Pesaran CIPS unit root test to check the stationarity. Pedroni and Kao tests and Westurland cointegration tests have been employed to confirm the cointegration among the variables. To estimate the long-run relationship, we have utilized DOLS and FMOLS techniques. Moreover, to determine the causality directions, we have employed Dumitrescu-Hurlin causality test. The results show that there was a bidirectional causality from energy use, FDI, GDP and patents to $\mathrm{CO}_{2}$ emissions. There was also a bidirectional causality from GDP to FDI. A unidirectional causality was detected 
from $\mathrm{CO}_{2}$ emissions, energy use and FDI to trademark. Moreover, one-way causalities were detected from trade openness to $\mathrm{CO}_{2}$ emissions, energy use to patents and patents to FDI. The results of the study indicate that there is a strong cross-sectional dependence among the underlying variables of the study in the panel of ASEAN countries due to rising economic interdependence among the countries. Secondly, the study found that energy use and trade openness significantly increases $\mathrm{CO}_{2}$ emissions in ASEAN countries. On the other hand, FDI, GDP and patents markedly depress $\mathrm{CO}_{2}$ emissions. The findings depict that energy use and trade openness harms the environment by escalating $\mathrm{CO}_{2}$ emissions while FDI, GDP and patents improve the environment by depressing $\mathrm{CO}_{2}$ emissions.

\section{Policy Recommendations}

This study proposes some policy recommendations for the government and policy-makers. As energy use results in rising $\mathrm{CO}_{2}$ emissions in the region, therefore policy-makers should encourage renewable energy investment for a sustainable environment. Renewable energy sources such as wind energy and solar energy are environmentally friendly and efficient to mitigate $\mathrm{CO}_{2}$ emissions in the whole world, including developed and developing countries. Moreover, the governments and policy-makers should utilize technology innovation for mitigating the effects of $\mathrm{CO}_{2}$ emissions; for instance, the process of waste recycling during the production process can reduce pollution. For this purpose, research and development funds should be raised for a sustainable, energy-efficient and technologyintensive production process. All this could be done by incorporating public and private sectors for cleaner production processes which lead to environmental sustainability. There is a need for efficient collaboration between developing and developed nations for mitigating the effects of $\mathrm{CO}_{2}$ effects because environmental sustainability is a common issue all over the world. Policy-makers should encourage foreign investors to invest in low-carbon and energy-efficient technologies by offering tax incentives. Regarding the matters of trade openness, governments should stimulate green trade liberalization for environmental sustainability. These policies will not be only useful for the sustainability of the environment but also result in rising FDI in the region.

\section{Future Research}

Considering the importance of the topic, the same study can be done in other regions as well. Future researchers can also do a comparative analysis of different regions such as SAARC, BRICS, ASEAN, BRI countries, G8 countries, etc.

\section{Acknowledgements}

This work was supported by National Social Science Foundation of China, Grant No. 18BJY105.

\section{Conflict of Interest}

The authors declare no conflict of interest.

\section{References}

1. IEA. World Energy. IEA, 2017.

2. SUN H., PING, TARIQ G., HARIS M., MOHSIN M. Evaluating the environmental effects of economic openness: evidence from SAARC countries. Environmental Science and Pollution Research, 26 (24), 24542, 2019.

3. CIOCA L.I., IVASCU L., RADA E.C., TORRETTA V., IONESCU G. Sustainable development and technological impact on $\mathrm{CO}_{2}$ reducing conditions in Romania. Sustainability (Switzerland), 7 (2), 1637, 2015.

4. GAO X., ZHANG W. Foreign investment, innovation capacity and environmental efficiency in China. Mathematical and Computer Modelling, 58 (5-6), 1040, 2013.

5. SSALI M.W., DU J., MENSAH I.A., HONGO D.O. Investigating the nexus among environmental pollution, economic growth, energy use, and foreign direct investment in 6 selected sub-Saharan African countries. Environmental Science and Pollution Research, 26 (11), $11245,2019$.

6. AL-MULALI U., WENG-WAI C., SHEAU-TING L., MOHAMMED A.H. Investigating the environmental Kuznets curve (EKC) hypothesis by utilizing the ecological footprint as an indicator of environmental degradation. Ecological Indicators, 48, 315, 2015.

7. GIELEN D., BOSHELL F., SAYGIN D., BAZILIAN M. D., WAGNER N., GORINI R. The role of renewable energy in the global energy transformation. Energy Strategy Reviews, 24 (June 2018), 38, 2019.

8. BOLTON R., FOXON T.J. Governing Infrastructure Networks for a Low Carbon Economy: Co-Evolution of Technologies and Institutions in UK Electricity Distribution Networks. Competition and Regulation in Network Industries, 12 (1), 2, 2011.

9. DOGAN E., SEKER F. Determinants of $\mathrm{CO}_{2}$ emissions in the European Union: The role of renewable and nonrenewable energy. Renewable Energy, 94 (2016), 429, 2016.

10. LIOBIKIENĖ G., BUTKUS M. Environmental Kuznets Curve of greenhouse gas emissions including technological progress and substitution effects. Energy, 135, 237, 2017.

11. SHAHBAZ M., NASIR M.A., ROUBAUD D. Environmental degradation in France: The effects of FDI, financial development, and energy innovations. Energy Economics, 74, 843, 2018.

12. DAUDA L., LONG X., MENSAH C.N., SALMAN M. The effects of economic growth and innovation on $\mathrm{CO}_{2}$ emissions in different regions. Environmental Science and Pollution Research, 26 (15), 15028, 2019.

13. LI J., LI S. Energy investment, economic growth and carbon emissions in China - Empirical analysis based on 
spatial Durbin model. Energy Policy, 140 (March), 111425, 2020.

14. SALAHUDDIN M., ALAM K., OZTURK I., SOHAG K. The effects of electricity consumption, economic growth, financial development and foreign direct investment on $\mathrm{CO}_{2}$ emissions in Kuwait. Renewable and Sustainable Energy Reviews, 81 (February), 2002, 2018.

15. KAIKA D., ZERVAS E. The Environmental Kuznets Curve (EKC) theory-Part A: Concept, causes and the $\mathrm{CO}_{2}$ emissions case. Energy Policy, 62, 1392, 2013.

16. DOGAN E., SEKER F. Determinants of $\mathrm{CO}_{2}$ emissions in the European Union: The role of renewable and nonrenewable energy. Renewable Energy, 94 (2016), 429, 2016.

17. MENSAH C.N., LONG X., BOAMAH K.B., BEDIAKO I.A., DAUDA L. The effect of innovation on $\mathrm{CO}_{2}$ emissions of OCED countries from 1990 to 2014. Environmental Science and Pollution Research, 10 (7), 1, 2018.

18. CAO W., ZHANG Y., QIAN P. The E ff ect of InnovationDriven Strategy on Green Economic Development in China - An Empirical Study of Smart Cities. International Journal of Environmental Research and Public Health, 16 (1), 1, 2019.

19. OWUSU P.A., ASUMADU-SARKODIE S. A review of renewable energy sources, sustainability issues and climate change mitigation. Cogent Engineering, 3 (1), 1, 2016.

20. IEA. International Energy Outlook 2016 (Vol. 0484), 2016.

21. LIU Y., SHENG Z., AZHGALIYEVA D. ASEAN: IMPACTS OF REGIONAL Asian Development Bank Institute, 2019.

22. HUANG Y., CHEN X., ZHU H., HUANG C., TIAN Z. The Heterogeneous Effects of FDI and Foreign Trade on $\mathrm{CO}_{2}$ Emissions: Evidence from China. Mathematical Problems in Engineering, 2019 (1), 1, 2019.

23. ERTUGRUL H.M., CETIN M., SEKER F., DOGAN E. The impact of trade openness on global carbon dioxide emissions: Evidence from the top ten emitters among developing countries. Ecological Indicators, 67 (97539), 543, 2016.

24. KOÇAK E., AYKUT Ş. The impact of foreign direct investment on $\mathrm{CO}_{2}$ emissions in Turkey: new evidence from cointegration and bootstrap causality analysis. Environmental Science and Pollution Research, 25 (1), 790, 2017.

25. SARKODIE S.A., STREZOV V. Effect of foreign direct investments, economic development and energy consumption on greenhouse gas emissions in developing countries. Science of the Total Environment, 646, 862, 2019.

26. TANG C.F., TAN B.W. The impact of energy consumption, income and foreign direct investment on carbon dioxide emissions in Vietnam. Energy, 79 (C), 447, 2015.

27. SHAHBAZ M., KUMAR A., NASIR M. The effects of fi nancial development, economic growth, coal consumption and trade openness on $\mathrm{CO}_{2}$ emissions in South Africa. Energy Policy, 61 (1), 1452, 2013.

28. JEBLI, M. BEN, YOUSSEF, S. BEN, OZTURK I. Testing environmental Kuznets curve hypothesis: The role of renewable and non-renewable energy consumption and trade in OECD countries. Ecological Indicators, 60 (2016), 824, 2016.

29. SOHAG K., AL MAMUN M., UDDIN G.S., AHMED A.M. Sectoral output, energy use, and $\mathrm{CO}_{2}$ emission in middle-income countries. Environmental Science and Pollution Research, 24 (10), 9754, 2017.
30. RASOULINEZHAD E., SABOORI B. Panel estimation for renewable and non-renewable energy consumption, economic growth, $\mathrm{CO}_{2}$ emissions, the composite trade intensity, and financial openness of the commonwealth of independent states. Environmental Science and Pollution Research, 25 (18), 17354, 2018.

31. CETIN M., ECEVIT E., YUCEL A.G. The impact of economic growth, energy consumption, trade openness, and financial development on carbon emissions: empirical evidence from Turkey. Environmental Science and Pollution Research, 25 (36), 36589, 2018.

32. KHAN M.K., KHAN M.I., REHAN M. The relationship between energy consumption, economic growth and carbon dioxide emissions in Pakistan. Financial Innovation, 6 (1), 1, 2020.

33. IŞIK C., KASIMATI E., ONGAN S. Analyzing the causalities between economic growth, financial development, international trade, tourism expenditure and /on the $\mathrm{CO}_{2}$ emissions in Greece. Energy Sources, Part B: Economics, Planning, and Policy, 00 (00), 1, 2017.

34. AYE G.C., EDOJA P.E. Effect of economic growth on $\mathrm{CO}_{2}$ emission in developing countries: Evidence from a dynamic panel threshold model Effect of economic growth on $\mathrm{CO}_{2}$ emission in developing countries: Evidence from a dynamic panel threshold model. Cogent Economics \& Finance, 90 (1), 1, 2017.

35. ASLANIDIS N., IRANZO S. Environment and development: is there a Kuznets curve for $\mathrm{CO}_{2}$ emissions ? Environment and development: is there a Kuznets curve for $\mathrm{CO}_{2}$ emissions? Applied Economics, 1 (November 2014), 37, 2009.

36. BHAT J.A. Renewable and non-renewable energy consumption - impact on economic growth and $\mathrm{CO}_{2}$ emissions in five emerging market economies. Environmental Science and Pollution Research, 2018 (1), $1,2018$.

37. SULAIMAN C., ABDUL-RAHIM A.S. The relationship between $\mathrm{CO}_{2}$ emission, energy consumption and economic growth in Malaysia: a three-way linkage approach. Environmental Science and Pollution Research, 2017 (1), $1,2017$.

38. HANIF I. Impact of economic growth, nonrenewable and renewable energy consumption, and urbanization on carbon emissions in Sub-Saharan Africa. Environmental Science and Pollution Research, 1 (March), 1, 2018.

39. HANNA R. US environmental regulation and FDI: Evidence from a panel of US-based multinational firms. American Economic Journal: Applied Economics, 2 (3), 158, 2010.

40. ALAM M.S., ATIF M., CHIEN-CHI C., SOYTAŞ U. Does corporate $\mathrm{R} \& \mathrm{D}$ investment affect firm environmental performance? Evidence from G-6 countries. Energy Economics, 78, 401, 2019.

41. YII K.J., GEETHA C. The Nexus between Technology Innovation and $\mathrm{CO}_{2}$ Emissions in Malaysia: Evidence from Granger Causality Test. Energy Procedia, 105, 3118, 2017.

42. YU Y., DU Y. Impact of technological innovation on $\mathrm{CO}_{2}$ emissions and emissions trend prediction on 'New Normal' economy in China. Atmospheric Pollution Research, 1 (May), 1, 2018.

43. DAUDA L., LONG X., MENSAH C.N., SALMAN M. The effects of economic growth and innovation on $\mathrm{CO}_{2}$ emissions in different regions The effects of economic growth and innovation on $\mathrm{CO}_{2}$ emissions in different regions. Environmental Science and Pollution Research, 1 (March), 1, 2019. 
44. LONG X., LUO Y., WU C., ZHANG J. The influencing factors of $\mathrm{CO}_{2}$ emission intensity of Chinese agriculture from 1997 to 2014. Environmental Science and Pollution Research, 25 (13), 1, 2018.

45. JORDAAN S.M., ROMO-RABAGO E., MCLEARY R., REIDY L., NAZARI J., HERREMANS I.M. The role of energy technology innovation in reducing greenhouse gas emissions: A case study of Canada. Renewable and Sustainable Energy Reviews, 78 (March 2017), 1397, 2020.

46. DINDA S. Production technology and carbon emission: long- run relation with short-run dynamics. Journal of Applied Economics, 21 (1), 106, 2018.

47. DONG K., SUN R., HOCHMAN G. Do natural gas and renewable energy consumption lead to less $\mathrm{CO}_{2}$ emission? Empirical evidence from a panel of BRICS countries. Energy, 141, 1466, 2017.

48. HUSSAIN J., KHAN A., ZHOU K. The impact of natural resource depletion on energy use and $\mathrm{CO}_{2}$ emission in Belt $\&$ Road Initiative countries: A cross-country analysis. Energy, 199, 117409, 2020.

49. PESARAN M.H. A simple panel unit root test in the presence of cross-section dependence. Journal of Applied Econometrics, 22 (2), 265, 2007.

50. PEDRONI P., PEDRONI PETER Panel Cointegration: Asymptotic and Finite Sample Properties of Pooled Time
Series Tests with an Application to the PPP Hypothesis, 2004.

51. KAO C. Spurious regression and residual-based tests for cointegration in panel data. Journal of Econometrics, 90 (1), 1, 1999.

52. DUMITRESCU E.-I., HURLIN C. Testing for Granger non-causality in heterogeneous panels. Economic Modelling, 29 (4), 1450, 2012.

53. PERERA F. Pollution from Fossil-Fuel Combustion is the Leading Environmental Threat to Global Pediatric Health and Equity: Solutions Exist. International Journal of Environmental Research and Public Health, 15 (16), 1, 2018.

54. CHOI J.Y., HAN D.B. The Links between Environmental Innovation and Environmental Performance: Evidence for High- and Middle-Income Countries. Sustainability (Switzerland), 10 (1), 1, 2018

55. INTISAR R.A., YASEEN M.R., KOUSAR R., USMAN M., AMJAD MAKHDUM M.S. Impact of trade openness and human capital on economic growth: A comparative investigation of asian countries. Sustainability (Switzerland), 12 (7), 2020.

56. LE H.P., VAN D.T.B. The energy consumption structure and African EMDEs' sustainable development. Heliyon, 6 (4), e 03822, 2020. 